NBER WORKING PAPER SERIES

WAGES IN THE FEDERAL AND

PRIVATE SECTORS

Steven F. Venti

Working Paper No. 1641

NATIONAL BUREAU OF ECONOMIC RESEARCH

1050 Massachusetts Avenue

Cambridge, MA 02138

June 1985

Prepared for the NBER Conference on Public Sector Payrolls, held

November 15-17, 1984 in Williamsburg, Virginia. Useful comments were provided by Tom Barthold, Alan Gustman, Jane Mather, Sharon Smith, and conference participants. Partial support from the Faculty Committee on Research at Dartmouth College is gratefully acknowledged. The research reported here is part of the NBER's research program in Labor studies and project in Government Budget. Any opinions expressed are those of the author and not those of the National Bureau of Economic Research. 
NBER Working Paper \#1641

June 1985

\title{
Wages in the Federal and \\ Private Sectors
}

\begin{abstract}
This study addresses the legal principle of "comparability" that ties federal sector wages to wages in the private sector. We first examine comparability by determining if workers with similar observed and unobserved characteristics receive the same wages in each sector. Estimates based on data from the 1982 CPS indicate males may have a slight wage advantage in the federal sector. Female workers earn substantially more in the federal sector than in the private sector. We then develop a choice-theoretic approach to the issue of comparability by applying a simple supply argument: a cost-minimizing federal employer would pay wages no higher than necessary to attract employees and el iminate queues for federal jobs. If the market pays equalizing differences for unique attributes of each sector, then this approach is not consistent with wage equality between the sectors. A model jointly determining sectoral attachment and wage offers is estimated by maximum likelihood. Results suggest the elimination of queues will require substantial wage reductions for both male and female federal employees.
\end{abstract}

Steven F. Venti

Department of Economics

Dartmouth college

Hanover, NH 03755 


\section{Introduction and Overview}

Pay comparability between the public and private sectors is supported by both equity and efficiency arguments. Equity considerations dictate a worker do no better or worse in the public sector than in the private sector. Efficiency considerations imply the federal sector pay no more than is necessary to attract an adequate supply of employees. Equal pay, it is presumed, will lead to "fair" competition for workers between the public and private sectors.

Several previous studies have attempted to determine if equal pay in the public sector has been attained. They have employed wage regressions to adjust observed differentials for observed quality and productivity differences among workers. Inability to "explain" pay differences by measured characteristics is taken to be evidence that equal pay is not the rule. Unexplained or residual differences in pay are interpreted as quasi-rents to employment in the higher paying sector.

The present analysis addresses two alternative interpretations of the "unexplained" difference between public and private wages. The first is unobserved differences in the productivity of workers in each sector. Despite the availability of large samples and detailed information in recent microdata files, we can never fully capture all worker specific differences. If workers are sorted between sectors on the basis of these unobserved factors the unexplained component of wage regressions may be more properly interpreted as individual differences rather than quasi-rents. One goal of the present analysis is to extend the wage regression approach to adjust for the effects of observed and unobserved productivity related personal characteristics.

The second alternative interpretation of the unexplained difference between public and private sector wages is equalizing (or compensating) wage differences for nonpecuniary job attributes. Workers may perceive fundamental differences between the public and private sectors. Distinguishing features of each sector, 
Wages in the Federal and Private Sectors

The legal principle of "comparability" has formally guided federal white-collar wage policy for the last 20 years. The legislation requires "federal pay rates be comparable with private enterprise pay rates for the same levels of work." 1 The principle has been interpreted and enforced to equalize wages between the federal and private sectors. Recent evidence suggests this objective has not been attained. Seminal work by Smith $(1976,1977,1981)$ and Quinn (1979) indicates federal workers may be "overpaid" relative to the ir private sector counterparts by as much as 15 to 20 percent.

This paper makes two additional contributions to the comparability debate. The first is another attempt to determine if federal and private sector wages are "equal" as mandated by current federal wage guidelines. Since individual productivity differences are valid reasons for pay differences between sectors, we extend the approach of Smith and Quinn to control for the effects of both observed and unobserved worker quality in order to isolate residual wage inequality between sectors.

The second contribution is an attempt to motivate a more choice-theoretic treatment of public-private wage differences. This approach is based on a simple supply interpretation of wage "comparability": as a cost-minimizing employer the public sector would set wages just high enough to attract the required work force. This interpretation appears to be the original motivation for comparability legislation. The approach suggests that if there exist equalizing differences in pay for nonpecuniary job attributes of each sector, a policy of equal wages is inappropriate. To resolve the issue of a "comparable" wage we develop and estimate a model of sectoral job attachment to identify the wage differential consistent with this interpretation of comparability. 
determine whether the worker will be employed in the government sector. More important, identification of the separate decisions permits a test for the existence of queues for federal jobs by revealing excess desired demand for government jobs at a given relative public-private wage. A related advantage of directly specifying the sectoral attachment mechanism is that it can be incorporated into the wage regression method to adjust observed differentials for both observed and unobserved productivity characteristics.

Before preceeding one shortcoming of the model deserves mention. This study focuses only on the wage component of pecuniary compensation. The principle of comparability has only recently been applied to nonwage compensation (Carow (1981)). Although the model does deal with nonwage job attributes, the analysis is geared to those attributes, unlike fringe benefits, that cannot be manipulated by employers. Of course the existence of positive. public-private wage differentials would be of less consequence if offset by other forms of pecuniary compensation such as fringe benefits. However, there is ample evidence this is not the case (Quinn (1979, 1982a, 1982b), Bellante and Long (1981)). These studies suggest federal-private wage differentials may understate total compensation differentials.

The results suggest wage equality between similar workers in the federal and private sectors was not achieved in 1982. After adjusting for both observed and unobserved productivity characteristics we find the federal wage structure exceeds the private sector wage structure by about 4 percent for males and 22 percent for females. We also attempt to estimate the wage differential that eliminates implicit queues for federal sector jobs. For the marginal worker this is the wage differential that equalizes the attractiveness of total compensation (wage and nonwage) packages offered by each sector. The estimates suggest elimination of queues would be achieved by reducing federal wages for males about 16 percent and federal wages for females by about 42 percent. 
which may be viewed either favorably or unfavorably by workers, include stability of employment, opportunity for internal promotion, unique nature of public service, pace of work, the bureaucratic work environment, etc. If the "return" to a job is viewed as a package containing both wage and nonwage components, then part of any public-private wage difference may be an equalizing difference for the nonwage job attributes. If workers trade off wages for these job attributes a policy of "equal wages" between sectors may lead to a federal wage scale that neither equalizes overall "returns" to workers in each sector nor elicits the appropriate supply response.

If wage differences between sectors are, in part, equalizing differences, then how can one determine if the federal sector "overpays"? Unlike the problem of unobserved productivity, the effects of equalizing differences cannot easily be dealt with in a wage regression framework. In particular, the conventional approach of standardizing wages for the effects of nonwage job attributes cannot be applied because some of the fundamental differences between the federal and private sectors (e.g. serving the public) cannot be easily measured. ${ }^{2}$ The alternative approach adopted here is to judge whether the government "overpays" based on implicit queues for public sector jobs. If the difference between public and private wage offers exceeds the equalizing difference in pay necessary to offset the difference between nonwage job aspects, then more individuals will desire government employment than there are public sector jobs. The wage differential that "just" eliminates the queue is, in a simply supply sense, the "comparable" wage differential.

The present analys is formulates and estimates a model of sectoral attachment at the individual level that permits rough calculation of the length of implicit queues for federal sector jobs. We identify determinants of worker preferences for federal sector employment and determinants of federal sector hiring choices. The separate decisions of employee and employer together 
Section 2 briefly outlines the objectives of comparability legislation and the pay setting mechanism in the federal government. The following section briefly reviews the wage regression approach and provides the motivation for the empirical work that follows. Section 4 lays out the employer-employee matching model that is central to our approach, and Section 5 discusses econometric issues. The description of data sources and presentation of results are contained in Sections 6 and 7 respectively. The findings are summarized in the final section.

\section{Setting Pay in the Federal Sector}

The federal government employs several different systems to determine pay. Slightly under one half of all federal civilian employees (mostly white collar) are classified under the General Service (GS) pay schedule. Another fifth (mostly blue collar) fall under the Federal Wage System (FWS). Remaining workers are covered by the Postal Service Schedule or one of several smaller pay plans for other agencies.

Each of the major federal pay systems is linked to private sector rates of pay. Reasons for doing so are set forth in the Federal Salary Reform Act of 1962 which established the comparability principle for workers covered by the GS:

\footnotetext{
"Adoption of the principle of comparability will insure equity for the federal employee with his equals throughout the national economy - enable the government to compete fairly with private firms for qualified personnel - and provide at last a logical and factual standard for setting Federal Salaries." (reprinted in President's Panel (1976), p. 8)
}

Having set this objective, an elaborate mechanism was established to annually adjust federal pay to private pay rates. In March of each year the Bureau of Labor Statistics undertakes a national white collar salary survey. 
This information is used to assign rates of pay to jobs in the public sector such that federal pay rates are comparable to "private enterprise pay rates for the same levels of work."3 A number of factors interfere with pursuit of this objective. First, it is often difficult to compare jobs in the public sector with jobs in the private sector (air traffic controllers, judges, etc.). Second, there are a number of technical problems with the BLS survey that may make the private sector comparison group a biased sample of all private sector workers. 4 Finally, in nine of the past 13 years, and not since 1976, have the pay raises suggested by the technical analyses been fully accepted by the executive and legislative branches. As a consequence there is good reason to suspect the comparability process may have strayed from its objective.

Although in principle federal wage schedules assign rates of pay to jobs not individuals, application of the system provides some flexibility to tailor compensation to fit individuals. To attract or retain workers, while remaining within the confines of the GS or FWS, federal employers can reclassify jobs upward (grade creep), speed up promotions, lower credentials for jobs, or give unduely large credit to previous work experience. In addition, upper level managers are eligible for merit pay bonuses. Borjas (1980) present some evidence on wage variation within the federal sector.

\section{The Wage Regression Approach}

The wage regression approach used by both Smith and Quinn, has previously been applied to race and sex differentials. An important distinction between these applications and the present application is that sectoral attachment, unlike race and sex, is a "choice" variable. The method compares earnings or wages between similar workers in each sector. It poses the hypothetical question: "What would a person with some given set of observed characteristics 
(education, sex, race, etc.) earn in each sector?" Unexplained or residual differences in pay between sectors are interpreted as quasi-rents to employment in the higher paying sector.

A serious empirical problem arises because choices not taken are not observed. Associated with each worker is a public sector wage or a private sector wage, but never both. The wage a private sector worker would earn if he were to obtain a public sector job is not observed, nor is the wage a government worker would earn in a private sector job. Direct wage comparisons are impossible. The best one can do is somehow impute an alternative wage for each worker. Inevitably this requires basing the analysis on workers employed in one sector or the other.

Smith and Quinn perform these imputations using the results of OLS wage equations fitted to each sector. Parameter estimates based on employed private sector workers are used to predict what "public sector workers would earn in the private sector." 5 The portion of the wage differential that cannot be explained by differences in measured characteristics between workers in each sector is interpreted as the extent of overpayment: a quasi-rent to employment in the higher paying sector.

Such an interpretation, however, hinges on two crucial assumptions. First, the disturbances in each wage equation are classically behaved. This assumption implies that given observed personal characteristics, workers are randomly distributed across sectors. Yet this restriction may be inconsistent with even the simplest models of employee and employer behavior which suggest sectoral attachment is a choice variable. Each employment match is the end result of a search process in which employees attempt to choose the job offering the greatest net advantage and employers try to obtain labor at the lowest cost. Many, if not most, of the factors involved in these choices (worker and employer preferences, job attributes, worker quality, etc.) are measured only 
imperfectly. If the matching process is effective we expect, say, a worker with unobserved skills valued most in one sector to be observed working in that sector. Thus self (or firm) selected samples, which imply different unobserved productivity characteristics of workers in each sector, may provide an alternative explanation of residual wage differences predicted by the wage regression technique.

The second assumption crucial to the Smith-Quinn interpretation is that pay oifferentials do not represent equalizing differences for nonpecuniary job attributes of each sector. If workers view the federal and private sectors as offering fundamentally different quantities of important nonwage job attributes, then workers will, in general, not face the same wage offers from each sector. The worker side of an employer-employee match suggests workers desire employment in the sector offering the most advantageous package of job attributes and wages. For some workers higher public sector wages may not be enough to offset dissatisfaction with nonwage aspects of public sector jobs. Other workers may view public sector jobs more favorably.

In a competitive labor market distributions of preferences across workers and nonwage attributes across jobs together determine the market tradeoff between components of the total (pecuniary and nonpecuniary) compensation package. 6 The presumption of "equilibrium" that permits interpretation of market tradeoffs as equalizing differences in pay is open to question in the public sector. Thus without the "equilibrum" assumption it is difficult to distinguish equalizing differences from noncompetitive quasi-rents.

The above arguments suggest wage differences between the public and private sectors can be decomposed into four "sources": a) observed productivity or skill differences, b) unobserved productivity or skill differences, c) equalizing differences in pay for nonpecuniary job attributes, and d) quasi-rents or 
overpayment by government employers. The Smith-Quinn application of the wage regression approach is directed towards the distinction between a) and d), but their framework can be modified to also consider b) and c). Let the (log) wage offer to the $i^{\text {th }}$ individual by the $j^{\text {th }}$ sector (federal or private) be given by:

$$
W_{i}^{j}=z_{i}^{\prime} \delta^{j}+\mu_{j}^{j}+a^{j}+\eta_{j}^{j} \quad j=f, p
$$

where $z_{j}$ is a vector of individual productivity characteristics, and $\delta^{f}$ and $\delta^{p}$ are vectors of sector specific weights. The $\mu_{j}^{j}$ represent the value of unobserved (to the analyst) productivity in each sector. Without loss of generality they are scaled to have zero mean in the population. The $a^{j}$ represent the market evaluation of nonwage job attributes in each sector and the $\eta_{j}^{j}$ are white noise.

The two assumptions required to interpret the unexplained residual as a quasi-rent can be more formally stated. Let $S_{j}$ be a binary variable that takes on a value of unity if the $i$ th individual is observed to be employed in the federal sector and a value of zero otherwise. The assumption of no worker sorting implies unobserved productivity characteristics are distributed randomly across sectors:

$$
E\left(\mu_{j}^{j} / S_{j}=1\right)=E\left(\mu_{j}^{j} / S_{j}=0\right)=0 \quad j=f, p
$$

The assumption of no equalizing differences in pay implies:

$$
E\left(a^{f}\right)=E\left(a^{p}\right)
$$

If both of these assumptions are satisfied then separate wage regressions estimated on subsamples of public and private sector workers will yield 
consistent estimates of $\delta^{f}$ and $\delta^{p}$. These parameter estimates can be used to decompose the observed wage differential into "explained" and "unexplained" components. This decomposition is generally evaluated at the sample means (indicated by bars): 7

$$
\Delta w=w^{f}-w^{p}=\left(\bar{z}^{f}-\bar{z}^{p}\right) \cdot \bar{\delta}+\left(\underline{\sigma}^{f}-\underline{\delta}^{p}\right)^{\prime} \underline{z} .
$$

The first term of the decomposition measures the part of the gross differential attributable to sectoral differences in the productivity characteristics of workers. The second term measures the quasi-rent to sectoral attachment.

We consider next the effect of relaxing assumptions (2) and (3) on the interpretation of the decomposition in (4). First, if workers are sorted between sectors on the basis of unobserved productivity characteristics, as sumption (2) will be violated. Empirical disturbances for the wage functions of observed workers in each sector (the estimation subsamples) will include nonrandomly selected samples from the population distributions of $\mu^{f}$ and ${ }_{\mu} P$. For workers employed in the public sector expected wages are:

$$
E\left(w_{i}^{f} / s_{i}=1\right)=Z_{j}^{\prime} \delta^{f}+E\left(\mu_{i}^{f} / s_{i}=1\right),
$$

and for workers in the private sector:

$$
E\left(w_{j}^{p} / s_{i}=0\right)=2 \delta_{i}^{p}+E\left(\mu_{i}^{p} / s_{i}=0\right)
$$

Wage regressions based on samples of observed workers may be misspecified due to an omitted variable measuring the expected effect of unobserved productivity characteristics given sectoral choice. 8 Estimated $\delta^{j}$ may be biased. In the context of the wage decomposition discussed above the effects of omitted productivity will be captured by the unexplained component 
$\bar{Z}^{\prime}\left(\underline{\delta}^{f}-\underline{\delta}^{P}\right)$. Unobserved productivity differences between workers in each sector may account for what previously appeared to be quasi-rents. Thus if assumption (2) does not hold consistent estimates of $\delta^{j}$ can only be obtained by jointly considering the wage and sector choice $\left(S_{j}=0,1\right)$ functions.

A more difficult problem to deal with is the presence of unmeasured job attributes. The $a^{j}$ in equation (1) represent market tradeoffs between wage offers and nonpecuniary job attributes in each sector. ${ }^{9}$ Ignoring complications due to unobserved productivity, violation of the "no equalizing differences" assumption (3) yields a wage decomposition:

$$
\Delta w=w^{f}-w^{p}=\left(\bar{z}^{f}-\underline{z}^{p}\right)^{\prime} \bar{\delta}+\left(\tilde{\delta}^{f}-\underline{\sim}^{p}\right) \cdot \bar{z}+\left(a^{f}-a^{p}\right) .
$$

The part of the gross differential not explained by differences in productive characteristics is comprised of "overpayment" of $\left(\delta^{f}-\delta_{\sim}^{p}\right) \cdot \bar{z}$ and the market value of nonwage job attributes $\left(a^{f}-a^{P}\right)$. The coefficients on the intercepts in the wage regression model will capture $\left(a^{f}-a^{p}\right)$, but because the difference in intercepts depends on the scaling and measurement of the $Z$ variables, one cannot retrieve $\left(a^{f}-a^{p}\right.$ ) (see Jones (1983)). Thus equalizing differences may also account for what previously appeared to be quasi-rents to sectoral attachment.

The troublesome effects of unobserved productivity characteristics $\left(\mu_{j}^{j}\right)$ and equalizing differences $\left(a^{j}\right)$ both arise from the sorting of workers between sectors. In the unobserved productivity case, workers end up in the sector yielding the greatest return to unobserved skills, all else constant. In the equalizing differences case workers choose the sector where, say, they "spend" the least for desirable job attributes. However the two effects are quite different because payment to the $\mu_{j}^{j}$ is worker-specific, but payment of $a^{j}$ 
determined at the market level, is not worker-specific. As a result, the $a^{j}$ will be independent of sectoral choice at the individual level. Unlike the troublesome effects of unobserved productivity, joint consideration of individual sectoral choice and wage offers will not resolve the problem. In the context of the wage regression approach to differentials, there is no easy way to separate the effects of equalizing differences from quasi-rents.

\section{Queues and the Determination of Federal Employment}

The preceeding section suggests the method of wage decomposition often employed to analyze wage differentials may fail to disentangle quasi-rents to employment in the government sector from the effects of either unobserved productivity characteristics or equalizing differences in pay. We consider an alternative approach to this problem. The approach is motivated by the simple supply argument that appears to be the original objective of comparability legislation: a cost-minimizing federal employer would set wages no higher than necessary to attract the required work force. If wages are above this level the government "overpays". Workers seeking quasi-rents to government employment will queue up for federal jobs.

Evidence of queues is our indicator of overpayment. As a practical matter the length and composition of these queues will rarely be observed. It is likely that many workers who desire federal jobs at current relative wages are employed in the private sector and never formally seek employment. To determine whether the federal government overpays, we need to identify these workers.

In the absence of direct observation of worker preferences for federal sector employment we develop below a simple model of the "matching" or sorting process between workers and employers. The model is used to determine the length and composition of queues. An additional advantage in that the selection 
mechanism central to this model enables us to adjust wage regressions for the biasing effects of unobserved productivity characteristics.

The model contains two sectors (public and private) and many workers. To focus attention on the fundamental differences between sectors (job security, unique nature of public service, bureaucratic work environment, etc.) we assume all employers within each sector are homogeneous. According to our characterization, certain nonwage job attributes are intrinsic to the government in its capacity as employer. These attributes are thus considered fixed neither sector can provide the unique attributes of the other sector at any cost. It follows that employers in each sector are primarily concerned with wage offers (given the market value of job attributes) rather than manipulating packages of wages and job attributes.

Unlike employers, who are of only two types, workers have heterogeneous tastes and preferences. Associated with each sector is a wage structure that relates the wage offered each worker to the worker's bundle of productivity characteristics. We assume all workers are aware of the best wage offers they could obtain in each sector. We focus on two choices; one by employees and one by employers.

First, at the prevailing public-private relative wage workers decide whether they prefer public or private sector employment. At the same time federal employers, perhaps anticipating queues for jobs, decide how they will select workers from the pool of potential employees demanding jobs. Given exogenous (legislated) levels of both employment and the federal wage scale, employers adopt a set of hiring standards to ration workers from the queve. 10

A worker will be employed in a particular sector if the worker both desires employment in that sector and the sector chooses to hire the worker. In addition, some workers may be either unemployed or out of the labor force. In the present analysis we deal only with employed persons. Moreover, we assume 
all workers can obtain a job in the private sector if needed, although many of these workers may prefer emplayment in the public sector. This assumption is consistent with the presumption of implicit queues for government jobs, that is, many private sector workers may prefer federal sector jobs at current relative wages between the sectors.

We call the sector preference decision of workers the "job acceptance" decision because it implicitly answers the hypothetical question: "Would the individual accept a federal sector job if offered (at some specified relative wage)?" We denote the employer decision to ration employment the "job offer" decision because it implicitly answers the hypothetical question: "Would the federal sector offer this individual a job if the individual applied?" The job acceptance decision is based on a utility comparison between packages of wages and nonwage job attributes offered by each sector. The job offer decision follows from cost minimizing behavior by employers. In particular, the federal sector attempts to select those workers from the queue (identified by productivity characteristics) that are most productive given the wage the federal sector must offer.

It is also important to recognize the hiring standards employed by the federal sector at a point in time are derived from a single point on the public sector demand curve for labor. At this point the wage is above the "competitive" level and queues result. The job offer decision summarizes how workers are chosen from the queues. At other points on the public sector demand curve - representing say, alternative budgets specifying different wage and employment levels - different hiring standards will be in effect.

This rather narrow formulation of the job offer decision is the consequence of not modelling the general equilibrium determination of public and private sector wages at the macro level. Thus one must bear in mind the hiring standards we specify may be useful predictions of the likelihood of choosing a 
marginal worker from the queue, but the same hiring standards would be inappropriate for nonmarginal changes in any of the factors that affect the length of the queue. 11

More formally we consider first the worker, or job acceptance side of the employment match. For each individual the decision to seek work in a particular sector will depend on the worker's evaluation of nonwage job attributes offered hnd on the potential wage that could be earned in each sector. The federal sector is fundamentally different from the private sector due to certain nonwage aspects of the job. Workers with different characteristics may vary in the ir evaluation of the nonwage aspects of each sector. These heterogeneous preferences may, in part, be represented by worker characteristics $x_{j}$. Worker choice between sectors also depends on relative wages. We denote the log wage differential between sectors as $\left(w^{f}-w^{p}\right)$, where $w^{f}$ and $w^{p}$ are the log wage offers individual $i$ would receive should the individual obtain employment in the federal (f) or private (p) sectors. We represent worker preference or desire for employment in each sector by $h_{j}^{f}$ and $h_{j}^{p}$ where: 12

$$
h^{f}=x_{-1}^{\prime} \beta^{f}+\alpha^{f}\left(w^{f}-w^{p}\right)+e^{f}
$$

$$
h^{P}=X_{\sim}^{\prime} \beta^{p}+\alpha^{p}\left(w^{f}-w^{p}\right)+e^{p} .
$$

The ${ }^{j}$ indicate the relationship between measured characteristics and tastes for work in each sector. The $\alpha^{j}$ measure the sensitivity of worker sectoral choice to the relative wage differential. Thus the $\beta^{\prime}$ 's and $\alpha$ 's together characterize each individual's evaluation of job packages offered by each sector. The $e^{j}$ represent unobserved worker heterogeneity.

From equation (5) it follows that an individual will desire to work in the federal sector if $h^{f}-h^{p}>0$. Let $p_{1}=h^{f}-h^{p}$ be: 


$$
\begin{aligned}
P_{1} & =\underset{\sim}{x}\left(\underline{\beta} f-\underline{\beta}^{p}\right)+\left(\alpha^{f}-\alpha^{p}\right)\left(w^{f}-w^{p}\right)+\left(e^{f}-e^{p}\right) \\
& =\underset{\sim}{X_{1}^{\prime} \sim 1}+\alpha_{1}\left(w^{f}-w^{p}\right)+e_{1} .
\end{aligned}
$$

If sectoral attachment was purely a supply decision then this equation would determine sectoral choice. However the proportion of workers desiring federal employment may exceed the number of jobs available in the government sector. For example, a private sector worker may be qualified for and desire a Post office job at some favorable (to the worker) $w^{f}-w^{p}$, yet the worker can do no more than queue up for the job.

To determine observed sectoral attachment we need to bring in the employer or job offer side of each match. At issue are the standards used by the federal sector to ration the queue of potential employees. We assume the objective of the federal sector is to maximize worker productivity per dollar spent on labor input. Towards this end we define a job offer function that evaluates each potential employee by productivity characteristics $\left(\underline{x}_{-2}\right)$ and the absolute cost $w^{f}$. Let $P_{2}$ be an index of the desirability of a worker to the federal government:

$$
P_{2}=\underset{-2 \sim 2}{X}{ }^{\prime} \beta \alpha_{2} w^{f}+e_{2}
$$

The matching process that generates observed sectoral attachment can now be made more explicit. Since neither $P_{1}$ nor $P_{2}$ are directly observed we can arbitrarily scale each such that $P_{j}>0$ indicates a worker will accept a public sector job $(j=1)$ or the government will hire the worker $(j=2)$ and $P_{j} \leq 0$ indicates the workers does not desire a public sector job $(j=1)$ or will not be hired $(j=2)$. Then, a worker is employed in the federal sector with probability: 
(8)

$$
P^{*}=\operatorname{Prob}\left[P_{1}>0, P_{2}>0\right] \text {. }
$$

We emphasize that the functions $P_{1}(\cdot)$ and $P_{2}(\cdot)$ are population relationships in the above model. All workers have relative preferences for federal versus private sector work and the public sector can potentially evaluate all workers. $P_{1}$ tells us which workers implicitly enter the queue and $P_{2}$ indicates which individuals will be chosen. 13 Some workers that would be acceptable to the federal government do not desire federal employment and thus remain in the private sector. Similarly, many private sector workers may desire employment in the federal sector but are never hired. It is in this spirit that we refer to $P_{1}(\cdot)$ as the "job acceptance" decision (would the individual accept a federal sector job if offered?) and $P_{2}(\cdot)$ as the "job offer" decision (would the federal sector hire an individual if that individual were to appear in the queue?).

\section{Estimation Issues}

Equation (8) indicates an individual will be observed to be employed in the federal sector with bivariate probability $p^{*}$. The probability of observing an individual to be employed in the private sector is 1-p*. If both $w^{f}$ and $w^{p}$ are known for each worker and $e_{1}$ and $e_{2}$ are distributed joint normal the parameters of $P_{1}$ and $P_{2}$ can be estimated directly. 14

Poirier (1980) has shown that identification can be achieved through a single exclusion restriction. The problem is one of choosing variables that determine either the job acceptance or job offer decisions, but not both. As a practical matter we feel there are several defensible restrictions we can impose. However, rather than relying solely on exclusion restriction we also 
tap an additional source of identification by using information on prior employment status of individuals.

Let $S_{t-1}$ and $S_{t}$ indicate employment status in periods $t-1$ and $t$ respectively, where $S_{t}=0$ indicates private sector attachment and $S_{t}=1$ indicates federal sector attachment. Further identification is provided by assuming all workers with federal sector jobs in period $t-1$ may, if they choose, remain employed in the federal sector in period $t$, that is, all federal sector separations are voluntary. Evidence for 1982, the year of our data, provides support for this assumption. For example, Executive branch employment dropped by over 113,000 in the first two years of the Reagan Administration. Over 90 percent of this reduction was achieved through normal processes of attrition (and early retirement) rather than by reduction-in-force procedures (separations, downgrades, or lateral reassignments).15

Let $\pi^{\mathrm{mn}}$ be the probability of observing an individual with employment pattern $S_{t-1}=m$ and $S_{t}=n$. The above assumption implies the likelihood an individual will be observed to make the $\left\{S_{t-1}=1, S_{t}=0\right\}$ transition is the joint probability of being offered a federal job in period $t\left(P_{2}>0\right)$, but not accepting it $\left(P_{1} \leq 0\right): 16$

$$
\pi^{10}=\operatorname{Prob}\left[P_{1} \leq 0, P_{2}>0\right]
$$

For the individual known to make this transition other combinations of job acceptance and offer decisions resulting in private employment $\left(\left(P_{1}>0, P_{2} \leq 0\right)\right.$ and $\left.\left(P_{1} \leq 0, P_{2} \leq 0\right)\right)$ are assumed to occur with zero probability.

The 1 ikelihoods of observing remaining transition patterns of employment are unaffected by the assumption. We have: 
(10)

$$
\begin{aligned}
\pi^{00} & =\operatorname{Prob}\left[P_{1} \leq 0, P_{2}>0\right]+\operatorname{Prob}\left[P_{1} \leq 0, P_{2} \leq 0\right]+\operatorname{Prob}\left[P_{1}>0, P_{2} \leq 0\right] \\
& =1-\operatorname{Prob}\left[P_{1}>0, P_{2}>0\right] \\
\pi^{01} & =\operatorname{Prob}\left[P_{1}>0, P_{2}>0\right] \\
\pi^{11} & =\operatorname{Prob}\left[P_{1}>0, P_{2}>0\right] .
\end{aligned}
$$

For workers in the federal sector in period $t$ we cannot distinguish between transitions $\left\{S_{t-1}=0, S_{t}=1\right\}$ and $\left\{S_{t-1}=1, S_{t}=1\right\}$, so $\pi=\pi{ }^{01}=\pi 11$. However for workers in the private sector in period $t$ we can distinguish between those employed in the government sector in the prior period $\left(\pi^{10}\right)$ and those not employed in the private sector in the prior period $\left(\pi^{00}\right)$.

Both wage offers $w^{f}$ and $w^{p}$ enter each of the $\pi^{m n}$. Up to this point we have considered them known. Although individual workers may be aware of wage offers in each sector, the observed data contain one or the other. We deal with this problem by explicitly incorporating these wage offers in the model. To do so, a slight reparameterization is useful. Let $\hat{w}^{f}=Z^{\prime} \delta^{f}$ and $\hat{w}^{P}=Z^{\prime} \delta P$. Then equations (1), (6), and (7) can be rewritten (omitting individual subscripts) as:

$$
\begin{aligned}
& P_{1}=\underset{-1-1}{X^{\prime} \beta}+\alpha_{1}\left(\hat{w}^{f}-\hat{w}^{p}\right)+\varepsilon_{1}=p_{1}^{*}+\varepsilon_{1} \\
& P_{2}=\underset{-2 \sim 2}{X^{\prime} \beta}+\alpha_{2} \hat{w}^{f}+\varepsilon_{2}=p_{2}^{*}+\varepsilon_{2} \\
& w^{f}=\underline{Z}^{\prime} \delta^{f}+\varepsilon_{3} \\
& w^{p}=Z^{\prime} \delta^{p}+\varepsilon_{4}
\end{aligned}
$$

where, 


$$
\begin{aligned}
& \varepsilon_{1}=\alpha_{1}\left(\varepsilon_{3}-\varepsilon_{4}\right)+e_{1} \\
& \varepsilon_{2}=\alpha_{2} \varepsilon_{3}+e_{2} \\
& \varepsilon_{3}=\mu^{f}+\eta^{f} \\
& \varepsilon_{4}=\mu^{p}+n^{p} .
\end{aligned}
$$

The unidentified $a^{j}$ are captured by coefficients on the intercept contained in 2. To maintain full generality the reduced form disturbances are joint iy distributed with density $f\left(\varepsilon_{1}, \varepsilon_{2}, \varepsilon_{3}, \varepsilon_{4}\right)$.

We are now able to derive the likelihood function of the sample. Using our earlier classification scheme we can partition sample observations into three categories. These categories and the contribution of each to the likelihood function of the sample are:

1) Al1 federal sector workers:

$$
\pi^{01}=\pi^{11}=\operatorname{Prob}\left[P_{1}>0, P_{2}>0, w^{f}-\hat{w}^{f}\right]
$$

2) Private sector workers with prior federal sector status:

$$
\pi^{10}=\operatorname{Pr}\left[P_{1} \leq 0, P_{2}>0, w^{P}-\hat{w}^{P}\right]
$$

3) Private sector workers with no prior federal sector status:

$$
\pi^{00}=1-\operatorname{Pr}\left[P>0, P>0, W^{P}-\hat{w}^{P}\right] .
$$

Since $w^{f}$ and $w^{P}$ are never both observed for the same individual each of these expressions is based on trivatiate density derived from $f\left({ }^{\cdot}\right)$ by "integrating out" either $\varepsilon_{3}$ or $\varepsilon_{4}$. For example, $\pi^{10}$ is based on the density: 


$$
g\left(\varepsilon_{1}, \varepsilon_{2}, \varepsilon_{4}\right)=\int_{-\infty}^{\infty} f(\cdot) d \varepsilon_{3},
$$

which enables us to calculate:

$$
\pi^{10}=\int_{-\infty}^{-p_{1}^{*}} \int_{-p_{2}^{*}}^{\infty} g\left(\varepsilon_{1}, \varepsilon_{2}, w^{P}-\hat{w}^{p}\right) d \varepsilon_{2} d \varepsilon_{1}
$$

Remaining probabilities are based on similar expressions.

Let $n_{1}, n_{2}, n_{3}$ refer to the subsamples of observations from the appropriate categories. The natural log of the likelihood function of the sample is:

$$
L=\sum_{n_{1}} \log \left(\pi^{1}\right)+\sum_{n_{2}} \log \left(\pi^{10}\right)+\sum_{n_{3}} \log \left(\pi^{00}\right)
$$

where $\pi^{1}=\pi^{01}=\pi^{11}$. The model described by this likelihood function may be considered an endogenous switching model with a bivariate regime classification function.

The joint density $f(\cdot)$ is assumed joint normal with mean vector zero and covariance matrix with typical element $\sigma_{i j}$. Following the conventional probit normalization we set $o_{11}=0_{22}=1$. Because $\varepsilon_{3}$ and $\varepsilon_{4}$ are never jointly observed, ${ }^{0} 34$ is not identified in this model. The parameter vector is thus:

$$
\Omega=\left\{\beta_{1}, \beta_{2}, \alpha_{1}, \alpha_{2}, \delta^{f}, \delta^{p}, o_{12}, o_{13}, o_{14}, o_{23}, o_{24}, o_{33}, o_{44}\right\} .
$$

The likelihood function is maximized with respect to $\Omega$ using a modified scoring algorithm proposed by Berndt, Hal1, Hall, and Hausman (1974).

\section{Data}

The primary data source used for estimation is the Current Population Survey (CPS) for the second quarter (Apri1, May, June) of 1982. This source has several advantages over other surveys. Sampling procedures based on rotation 
groups make it possible to match respondents in adjacent years. This permits creation of the large longitudinal file we need to classify observations by previous period employment status. ${ }^{17}$ Another advantage over other longitudinal data files (NLS, PSID) is the CPS provides detailed information on the level (federal, state, or local) of government. 18

The data used include a 11 respondents who worked in either the federal or private sectors in 1981 and also worked in either the federal or private sectors in 1982. Any individual that did not work in either year, or worked in state or local government in either year is excluded. Although we recognize these exclusion restrictions are not exogenous, the costs of taking explicit account of them are prohibitive.

The sample contains 6064 men and 4561 women. Summary statistics for these data are contained in Table 1. Definitions of most variables are obvious. The dependent variable is the natural log of the hourly wage rate calculated by dividing usual weekly earnings by usual hours worked per week. Region variables are based on census definitions and unemployment rates are at the state level. The variable "Percent Federal Employment" is an index of the federal presence in each state obtained by dividing federal civilian employment by total employment in each state. Finally, the variable "Years of Potential Experience" is calculated as age minus schooling minus five.

One potentially important variable not included in our analys is is union status. This exclusion may be defended on grounds that it is preferable to let union effects implicitly enter the model in reduced form rather than deal directly with the endogeneity of union status. In any event, the absence of information on collective bargaining prohibited the analys is of union status. 19 


\section{Results}

\section{A Parameter Estimates}

Equation (6) suggests an individual's desire for employment in the public sector will depend on relative wage offers $\left(w^{f}-w^{p}\right)$. According to this formulation a percentage increase in $w^{f}$ will have the same effect as a percentage decrease of the same percentage magnitude in $w^{p}$. However, an empirical problem arises because of the omission of relevant information on pensions and other nonwage forms of pecuniary compensation. Theory suggests an inverse relationship between wages and fringes in the compensation package. This prediction has received little empirical support (see Smith an Ehrenberg (1983)). Instead, evidence indicates the public sector (or high wage employers in general) may offer workers both high wages and attractive fringes. 20 Moreover, the pension component of the compensation package is often an actuarial (frequently linear) function of wage payments. This suggests workers will not be ind ifferent between changes in relative wages due to changes in federal sector (high fringe) wages on the one hand and private sector wages (low fringe) on the other. To allow for this possibility we generalize our empirical formulation of the job acceptance decision to permit asymmetric responses to public and private sector wages:

$$
P_{1}=\underset{-1-1}{X} \frac{\beta}{x_{1}} w^{f}+\alpha_{1}^{p} w^{p}+e_{1}
$$

Parameter estimates for this version of the model are presented in Table 2 for males and Table 3 for females. The first two columns of each table present results for the job acceptance $\left(P_{1}\right)$ and job offer $\left(P_{2}\right)$ equations. Remaining columns contain estimated wage functions for the federal sector $\left(w^{f}\right)$ and private sector $\left(w^{p}\right)$. Estimates of the $o_{i j}$ are presented at the bottom of each table.

We first consider estimates for the job offer and acceptance decisions for males. Since most of the individual parameters are not of primary interest we 
will be brief. Higher federal sector wage offers increase the probability a worker will desire to work in the public sector but decrease the likelihood the worker will be hired. Worker preference for the public sector decreases with the private sector wage offer. Comparison of $\alpha_{1}^{f}$ and $\alpha_{1}^{p}$ suggests worker choice is more sensitive to federal wages than to private sector wages. This difference may, as the discussion above indicated, reflect more generous fringe benefits in the federal sector.

other estimates reveal married or previously married individuals are more likely to desire employment in the federal sector than never married individuals. Nonwhites are less likely to desire government employment but more likely to receive a public sector job offer. Workers in the South are both less likely to want and less likely to be offered federal jobs. The coefficient on the federal employment variable indicates federal presence in a state strongly increases the likelihood of a federal job offer.

We present the estimated wage functions for males in columns 3 and 4 of Table 2. Most, parameters of the wage functions are precisely measured. The estimated covariance parameters indicate wages and the matching process are not independent. This suggests OLS estimates of sectoral wage functions may be biased. We make some comparisons with OLS to investigate the extent of this bias in subsection $7 . C$.

The parameter estimates indicate wage functions in the federal and private sectors are slightly different in several respects. Nonwhites have a (insignificant) wage advantage in the federal sector but a wage disadvantage in the private sector. Federal wages appear to be lower outside of the South (which includes Washington, D.C.) but private sector wages are higher in all regions other than the South. The estimates indicate an additional year of education adds 3.7 percent to wages in the federal sector and 4.5 percent in the private sector (evaluated at means). An additional year of potential experience 
adds about 1.1 percent to wages in each sector.

For females the estimated $\alpha^{\prime} s$ again have the expected signs. Most of the other coefficients in the job offer, acceptance, and wage equations are of the same sign and approximate magnitude as the coefficients for males. A notable exception is the curious effect of education on the probability an individual will be offered a public sector job. For both males and females an additional year of education has the same effect on the job offer probability evaluated of mean (12.6) years of schooling. However additional years of schooling beyond the sample mean have much larger positive effects on the job offer probability for men than for women. Indeed, for women the effect of an additional year of schooling turns negative at slightly under 15 years of schooling.

\section{B Direct Wage Comparisons}

The advantage of joint estimation of wage offer functions and the sectoral choice mechanism in that the biasing effect of unobserved worker quality is eliminated. As Section 3 argued, the resulting "unexplained" wage differences may represent the combined effects of government payment of quasi-rents and equalizing differences. Direct wage comparisons cannot distinguish between these effects. However, "equal" wage structures is itself a current policy goal so these wage comparisons indicate how this goal has been met.

Before considering the estimates it is useful to clarify a problem of interpretation of direct wage comparisons. "Equal" wage structures is taken to mean a randomly chosen individual will face identical wage offers from each

sector $\left(\hat{w}_{j}^{f}=\hat{w}_{j}^{p}\right)$. This definition of "equal" wages implicitly takes a wage function based on all private sector workers as the standard of comparison. Whether this should be so is a policy issue we do not address here. Previous analyses (Smith, Quinn) have used the average wage of all private sector workers as the standard and, to compare our findings with theirs, we continue this 
tradition. However, one may argue the "correct" comparison group should include state and local employees, or be 1 imited to the unionized private sector, be restricted to large private employers, or contain only white males. Indeed, the puzzling question of why survey evidence used in federal wage policy (the PATC Survey) suggests federal workers are "underpaid", yet est imates based on the CPS samples indicate federal workers are "overpaid" may be the result of different comparison groups (see Freeman (1984)). In any event, the standard used in this section is the wage function of a random sample of all private sector workers. Our primary concern is the effect of observed and unobserved productivity characteristics on sectoral wage differences.

Predicted percentage wage differences between the federal and private sectors are presented in Table 4.21 The first row gives mean differences for each sex. In our sample males in the federal sector average 32.8 percent more and females 38.7 percent more than their counterparts in the private sector. The second row of Table 4 presents estimated federal-private differentials "adjusted" for differences in observed productivity related characteristics of workers in each sector. These estimates, based on the wage regression approach, indicate almost two-thirds of the male gross differential can be attributed to observed individual differences. The analogous figure for females is about 40 percent. Finally, parameter estimates from the model jointly estimating wage functions and the sectoral choice mechanism (row 4) suggest the "unexplained" wage difference is 4.2 percent for males and 22.1 percent for females. 22

It is interesting to compare these findings to the most recent published results (using 1978 data) of Smith (1981). Employing the wage regression technique she finds a wage advantage of 10 to 11 percent for males and 20 to 21 percent for females. These figures are remarkably clase to our reported oLS results in row 2 of Table 4. However, an important difference between these 
findings and those of Smith is she specified her wage equations with 12 variables (mostly quadratic and product terms involving experience, education, and marital status) not included in our specification. Row 3 of Table 4 presents the results of adding most of these same variables to our OLS wage functions. The wage advantage increases slightly to 12.1 percent for males and drops to 20.3 percent for females.

The comparison between rows 2 and 3 suggests wage regression estimates of the wage advantage may not be very sensitive to omitted variables. (many of the variables included in row 3 but not in row 2 are highly significant.) Therefore it is a bit surprising that the maximum likelihood (ML) correction for unobservables further reduces the wage advantage for males. Although computation costs prohibited inclusion of a variable list as exhaustive as Smith's in our ML model, the OLS results suggest the addition of these variables would probably have little effect. Thus observed wage differences appear to be attributable to unobserved as well as observed productivity differences for males, but for females the effect of unobserved characteristics is apparently nit.

\section{C Simulated Probabilities and Queues}

If employers pay no equalizing differences for sectoral differences in nonwage job attributes the above figures represent our best estimates of the federal-private wage advantage. If this is not the case, we need an alternative indicator of the "comparability" of wages. One such indicator is the length of queues for federal sector jobs.

Recall that neither the job acceptance nor the job offer decisions are directly observed. We can use the parameter estimates of the model to simulate these events. In Table 5 we present predicted marginal probabilities of job acceptance and job offer. These predictions are obtained by calculating 
probabilities for each member of the sample and then averaging.

The first entry in this table indicates the average predicted probability of job acceptance of males in the sample was 0.18 .23 our interpretation is that 18 percent of all sample men would accept a federal sector job if offered. The analogous figure for females is a bit higher, about 29 percent. This suggests that federal-private wage differentials are more attractive to women in this sample.

The job offer probabilities presented in the second row indicate 83 percent of all males would be acceptable to federal employers, but only 67 percent of females would be hired. This reflects the expected "reverse" sorting in the matching process, that is, most measured personal characteristics have opposite effects in the acceptance and offer decisions. In addition, the estimated correlations between unobserved factors entering each decision are also negative $(-0.87$ for males and -0.92 for females). Thus those individuals most 1 ikely to desire a federal sector job are also least likely to be offered a federal sector job. This pattern is most striking when the joint probability of being offered a job and accepting a job (the probability of being employed in the federal sector) is considered. If joining the queue (job acceptance) and being chosen from the queue (job offer) were independent, the probability of observing a worker in the federal sector would simply be the product of marginal probabilities: 0.134 for males and 0.160 for females. 24 However neither the acceptance nor offer decisions are pure random behavior, so the predicted joint probability based on the negative estimated correlation is 0.064 for males and 0.047 for females (row 3).

These simulated probabilities provide useful new information about the matching process. Yet they do not say much about whether wages are "comparable" between sectors. We can attempt to answer this more difficult question by 
noting that if the public-private wage differential observed in the sample exceeds the equalizing difference that must be paid to attract workers to the federal sector, then queues for federal sector jobs will result. If we ignore worker quality and concentrate on numbers of workers we are able to obtain an informal measure of the length of the queue by comparing the fraction of the workforce desiring government employment (at sample wages) to the fraction that is employed in the federal sector.

This indicator of the length of the queue, calculated as $\operatorname{Pr}\left(P_{1}>0\right) / \operatorname{Pr}\left(P_{1}>0, P_{2}>0\right)$ is presented in the last row of Table 5. This expression is the inverse of the probability that a worker desiring a federal sector job will be chosen from the implicit queue. Roughly three times as many men would be willing to work at the sample wage differential as will be hired at that differential. The analogous figure for women is double that of men.

\section{D. An Alternative Indicator of Comparability}

An alternative approach to comparability can be based on a simple supply argument: a cost-minimizing federal employer would pay wages no higher than necessary to attract the required workforce and el iminate the queues described above. This approach has considerable theoretical appeal. In particular, the inability of the wage regression approach to distinguish between payment of rents and payment of equalizing differences for job attributes is no longer a problem because each individual's choice of sector is based on an implicit valuation of both the wage and rionwage aspects of jobs.

This supply principle can be made operational by using the parameter estimates obtained in section 6 to simulate the employment effects of changes in federal wages. To simplify matters we consider only policies that alter federal wages by the same percentage amount for all individuals. Other policies that alter the return to individual attributes or otherwise result in different 
percentage changes across individuals are not considered. In the notation of the wage offer functions discussed earlier, all changes in federal wages are obtained by altering the intercept.

Let $\vec{c}$ be the proportion of male (or female) workers emplayed in the federal sector. The probability of job acceptance can be rewritten (using equation $\left.\left(6^{\prime}\right)\right)$ as:

$$
\tilde{P}_{1 i}=F\left[X_{-1 ; \sim 1}^{B}+\alpha_{1}^{f}\left(\hat{w}_{i}^{f}+k\right)+\alpha_{1}^{p_{\hat{w}}} p_{i}\right]
$$

where $F[\bullet]$ denotes the normal distribution function and the new term, $k$, approximates a constant (across individuals) percentage change in the federal wage offer.

Given the parameter estimates we can use (12) to simulate the number of persons desiring employment in the government sector for any change in federal wage offers. In particular, the federal wage reduction that eliminates queues given ty the $k$ that satisfies $1 / N \sum_{i=1}^{N} \bar{P}_{1 i}=\bar{c}$. This procedure yields values of $k$ of about minus 16 percent for males and minus 42 percent for females. This suggests the federal government could continue to attract a workforce of current size with substantially lower wages.

Several important issues are raised by these figures. First, since the simulation procedure fixes the level of employment but not labor "quality," one consequence of lower federal wages may be deterioration of the quality of the federal workforce. The severity of this problem depends on the relative importance of the federal wage structure $\left(w^{f}\right)$ and hiring standards $\left(P_{1}\right)$ in determining who enters and is chosen from queues. As an empirical matter the "quality" effect has been minimized by considering only constant percentage changes in wages. Apparently the number of individuals desiring employment in 
the federal sector is primarily a function of the wage level, and the "quality" (attributes) of individuals desiring federal employment is more strongly related to the wage structure (the relative valuation of individual attributes by each sector). A comparison of simulated workforces before and after the wage reduction indicates the quality problem is not severe. For example, the 16 percent wage reduction for males will reduce the average level of education of the male federal workforce from 13.9 years to 13.8 years. Comparable figures based on the 42 percent wage reduction for women are 13.1 and 12.8. Levels of work experience were slightly higher for the low wage federal workforce than for the high wage workforce.

Another issue is the particularly large response for women. Perhaps the most likely explanation is our choice of a private sector comparison group (see the discussion in Section 7.B). If the private sector is imperfect (unions, discrimination, monopoly, etc.) the wage the government must offer to attract workers will be affected. For instance, if there exists sex or race discrimination in the private sector, the price the federal sector must pay for its work force will be lower. Although payment of these lower wages may be cost effective given the imperfections in the private sector, it may be legally or politically inappropriate for the federal government to simply match (or slightly exceed) discriminatory wages. Thus perhaps some of the apparent government wage advantage, particularly for females, can be attribute to imperfections in the private sector labor market. Our results may indicate the private sector "underpays" certain groups of workers.

Finally, two additional 1 imitations of the model may also be relevant. First, some of the assumptions required to calculate $k$ are not likely to be satisfied. In particular, we have implicitly assumed the demand curve for public employees is perfectly inelastic: as relative wages change the "target" employment level $\bar{c}$ remains fixed. Finally, we note once again that the role of 
pensions in the public sector may complicate our interpretation of relative wage differences.

\section{Summary}

Our empirical effort is directed towards two goals. First, we seek to determine if wage structures in the federal and private sectors have been "equalized" by the federal comparability process. Our second goal is to develop a more choice-theoretic approach to the issue of wage comparability. A difficulty with previous work is that when markets do not clear, as is likely to be the case for the public sector, the conventional wage regression approach to comparability is unable to distinguish equalizing differences from quasi-rents. Explicit modelling of worker and employer choices appears to be an appealing alternative.

With respect to the first goal, a comparison of 1982 wages for federal workers and all private sector workers suggests wages were not equal. Although much of the gross differential in average wages can be explained by differences in observed and unobserved attributes of workers in each sector, federal sector wage advantages of about 4 percent for males and 22 percent for females remained unexplained.

With respect to the second goal we formulate and estimate a model permitting prediction of the wage differential that el iminates implicit queues for federal sector jobs. The estimates suggest the elimination of queues will require substantial reductions in federal wages for both sexes. Subject to 1 imitations detailed in 7 , the simulations suggest the federal sector is able to attract a workforce of current size and roughly current "quality" by offering average wages 16 percent lower for men and 42 percent lower for women. 
Footnotes

IFederal Salary Reform Act of 1962.

${ }^{2}$ This is the standard method of estimating equalizing differences in the private sector where observed wage differentials can be assumed to be "equilibrium" differences. See Smith (1979), Brown (1980), and Duncan and Holmlund (1983) for examples. Quinn (1979) makes some adjustments for public-private differences in nonwage job attributes. See also Bellante and Link (1981)

${ }^{3}$ See President's Panel (1976), ch. 2. This is a brief description of GS pay determination. FWS pay rates are set to be "in line with prevailing levels for comparable work within a local wage area." Postal Service rates are set by collective bargaining, although "On a standard of comparability to the compensation and benefits paid for comparable levels of work in the private sector of the economy."

${ }^{4}$ See Smith $(1977,1982)$ and President's Panel (1976), Ch. 5. The most important is the minimum establishment size which leads to oversampling of high pay employers. Another problem is the lack of information on fringe benefits.

${ }^{5}$ Alternatively, wage functions can be estimated for public sector employees and the estimated coefficients can be used to predict what private sector workers would earn in the public sector. See Smith (1977), p. 49-52.

${ }^{6}$ See Smith (1979) or Rosen (1983).

7 We ignore the index number problem of choosing a base.

${ }^{8}$ See, for example, Heckman (1979).

${ }^{9}$ The $a^{j}$ say nothing about individual preferences for wages versus job attributes unless preferences are homogenous in the population or the particular individual is at the margin between sectors.

${ }^{10}$ In the short run we assume federal employers cannot use the wage mechanism to shorten the queue. This seems to be an accurate description of pay 
procedures for lower and middle level jobs, but it may be less valid for upper level jobs.

${ }^{11}$ A more elaborate and complete model specifying the mechanisms governing wage adjustments at the macro level is beyond the scope of this paper.

12 We omit the individual subscript where no ambiguity will result.

${ }^{13} P_{2}$ also indicates whether workers who do not enter the queue $\left(P_{1} \leq 0\right)$ would be chosen were they to enter the queue. Thus $P_{2}$ should not be interpreted as conditional on being in the queue.

${ }^{14}$ Empirical investigations of similar models in which wages enter in reduced form are Abowd and Farber (1981) and Farber (1983).

${ }^{15}$ See U.S. Office of Personnel Management (1983). The assumption is similar to the "job rights" assumption of Abowd and Farber (1981).

${ }^{16}$ Although period $t-1$ employment status is used to classify observations, we do not condition on prior employment status. Thus all arguments in the following probability expressions pertain to period $t$.

${ }^{17}$ Only about 15 percent of the respondents can be matched across one year (rotation groups four and eight). To obtain a large enough file we combined three monthly surveys.

${ }^{18}$ Information on level of government has always been collected as part of the CPS, but until 1979 this information was not available only sproadically. Availability of this information gives us a distinct advantage over some previous efforts using the CPS to analyse federal-private differentials in which only half of all public sector workers could be identified by industrial classification.

${ }^{19}$ One third of our sample does have recorded union status. These are not enough observations for a meaningful analysis. Both the rate of unionization and the nature of unionization differ between the public and private sectors. 
Thus unions may offer an "explanation" for noncomparability of wages. See Ehrenberg and Schwarz (forthcoming).

${ }^{20}$ In particular, federal pension contributions measured as a proportion of wages are several times greater than private sector contributions. See Leonard (1983) and Smeeding (1983).

${ }^{21}$ Percentage changes are calculated as $\left(e^{m}-1\right)$ where $m$ is the difference in logs.

${ }^{22}$ The last row of Table 4 is calculated as $\hat{W}^{f}-\hat{w}^{p}=\bar{X}^{\prime}\left(\hat{\beta}^{f}-\hat{\beta}^{p}\right)$. To obtain the standard error of this estimate we first calculate $\operatorname{var}\left(\underline{\sim}^{f}-\underline{\sim}^{\sim} p\right)=\underline{\sim}$ from the covariance matrix of parameters. The reported standard error is the square root of $\bar{X} \cdot \hat{\Sigma} \bar{X}$.

${ }^{23}$ This probabilitiy is not conditional on a job offer. Also, all probabilities are evaluated at the appropriate adjusted sample wage differences. ${ }^{24}$ The joint probability is calculated for each member of the sample and then averaged. In a heterogeneous population this joint probability will not equal the product of the two average marginal probabilities. 


\section{References}

Abowd, J. and H. Farber. 1982. "Job Queues and the Union Status of Workers." Industrial and Labor Relations Review. 35: 354-367.

Bellante, D. and A. Link. 1981. "Are Public Sector Workers More Risk Averse than Private Sector Workers". Industrial and Labor Relations Review. $34: 408-412$.

Bellante, D. and J. Long. 1981. "The Political Economy of the Rent-Seeking Economy: The Case of PublicEmployees and Their Unions." Journal of Labor Research. 2: 1-14.

Berndt, E., B. Ha11, R. Hal1, and J. Hausman. 1974. "Estimation and Inference in Nonlinear Models." Annals of Social and Economic Measurement 4: $653-665$.

Borjas, G. 1980. Wage Policy in the Federal Bureaucracy. Washington D.C.: American Enterprise Institute.

Brown, C. 1980. "Equalizing Differences in the Labor Market." Quarterly Journal of Economics. : :113-134.

Carow, R. 1981. "Total Compensation Comparability in the Evolution of Federal Compensation Policy," in P. Mieszkowski and G. Peterson, ed., Public Sector Labor Markets. Washington, D.C.: Urban Institute.

Duncan, G. and B. Holmlund. 1983. "Was Adam Smith Right After All? Another Test of the Theory of Compensating Wage Differentials." Journal of Labor Economics. 1: 366-379.

Ehrenberg, R. and J. Schwarz. forthcoming. "Public Sector Labor Markets". in 0. Ashenfelter and R. Layard, ed., Handbook of Labor Economics. North-Holland.

Farber, H. 1983. "The Determination of the Union Status of Workers". Econometrica. 51: 1417-1437. 
Freeman, R. 1984. "How Do Publ ic Sector Wages and Employment Respond to Economic Conditions." presented at the NBER conference on Public Sector Payrolls, Williamsburg, VA, Nov. 15-17.

Heckman, J. 1979. "Sample Selection Bias as a Specification Error." Econometrica. $47: 153-161$.

Jones, F. 1983. "On Decomposing the Wage Gap: A Critical Comment on Blinder's Method." Journal of Human Resources. 18: 126-130.

Leonard, H. 1983. "The Federal Civil Service Retirement System: An Analysis of its Financial Condition and Current Reform Proposals," presented at the NBER Conference on Pensions, Labor, and Individual Choice, Peurto Rico, March 23-26.

Poirier, D. 1980. "Partial Observability in Bivariate Probit Models." Journal of Econometrics. 14: 209-217.

President's Panel on Federal Compensation. 1976. Staff Report. Washington D.C.: GPO.

Quinn, J. 1979. "Wage Differentials Among 0lder Workers in the Public Sector." Journal of Human Resources. 14: 41-62.

- 1982a. "Compensation in the Public Sector: The Importance of

Pensions," in R. Haveman, ed., Public Finance and Public Employment. Wayne State University Press: Detroit.

- 1982b. "Pension Wealth of Government and Private Sector Workers." American Economic Review. 72: 283-287.

Rosen, S. 1983. "The Equilibrium Approach to Labor Markets." NBER working paper No. 1165.

Smeeding, T. 1983. "The Size Distribution of Wage and Nonwage Compensation: Employer Cost versus Employee Value," in J. Triplet, ed., The Measurement of Labor Cost. Chicago, 111.: University of Chicago Press. Smith, R. 1979. "Compensating Wage Differentials and Public Policy: A 
Review." Industrial and Labor Relations Review. 32: 339-352.

Smith, R. and R. Ehrenberg. 1983. "Estimating Wage-Fringe Trade-0ffs: Some

Data Problems," in J. Triplett, ed., The Measurement of Labor Cost.

Chicago, I11.: University of Chicago Press.

Smith, S. 1976. "Pay Differentials Between Federal Government and Private Sector Workers." Industrial and Labor Relations Review. 29: 179-197. - 1977. Equal Pay in the Public Sector: Fact or Fantasy. Princeton University: Industrial Relations Section. = 1981. "Public/Private Wage Differentials in Metropolitan Areas," in P. Mieszkowski and G. Peterson, ed., Public Sector Labor Markets. Washington, D.C.: Urban Institute. - 1982. "Prospects for Reforming Federal Pay." American Economic Review. $72: 273-277$.

U.S. Office of Personnel Management. 1983. OPM: The Year in Review, 1982. Washngton, D.C.: GPO. 
Table 1: Summary Statistics

\begin{tabular}{|c|c|c|c|c|}
\hline \multirow{2}{*}{ Variable } & \multicolumn{2}{|c|}{ Males } & \multicolumn{2}{|c|}{ Females } \\
\hline & Mean & S.D. & Mean & S.D. \\
\hline Iog Wage: Federal Sector & 2.41 & .39 & 2.05 & .40 \\
\hline Log Wage: Private sector & 2.13 & .50 & 1.72 & .43 \\
\hline Nonwhite & .10 & .30 & .12 & .33 \\
\hline Veteran & .42 & .49 & - & - \\
\hline Married & .73 & .44 & .58 & .49 \\
\hline Widowed, Divorced or Separated & .08 & .26 & .21 & .41 \\
\hline Central City & .21 & .41 & .24 & .43 \\
\hline SMSA but not Central City & .37 & .48 & .34 & .47 \\
\hline Northeast & .24 & .43 & .24 & .43 \\
\hline North Central & .27 & .44 & .27 & .44 \\
\hline West & .21 & .40 & .20 & .40 \\
\hline Percent Federal Employment & .03 & .06 & .03 & .07 \\
\hline Unemployment Rate & .09 & .21 & .09 & .21 \\
\hline Years of Education & 12.64 & 2.77 & 12.48 & 2.30 \\
\hline Years of Potential Experience & 21.66 & 13.94 & 21.20 & 14.18 \\
\hline Professional & .15 & .36 & .13 & .34 \\
\hline Managerial & .14 & .34 & .08 & .26 \\
\hline Clerical & .09 & .28 & .42 & .49 \\
\hline Craft & .27 & .44 & .03 & .17 \\
\hline Operative & .21 & .41 & .14 & .35 \\
\hline Laborer & .07 & .25 & .01 & .11 \\
\hline Number of observations & & 064 & & 61 \\
\hline
\end{tabular}


Table 2: Parameter Estimates for Males ${ }^{a}$

\begin{tabular}{|c|c|c|c|c|}
\hline Variable & $\begin{array}{c}\text { (I) } \\
\text { Job Acceptance } \\
\text { Probability } \\
\left(\mathrm{P}_{I}\right)\end{array}$ & $\begin{array}{c}(2) \\
\text { Job offer } \\
\text { Probability } \\
\left(\mathrm{P}_{2}\right)\end{array}$ & $\begin{array}{c}\text { (3) } \\
\text { Federal } \\
\text { Wage } \\
f \\
\left(w^{f}\right)\end{array}$ & $\begin{array}{c}(4) \\
\text { Private } \\
\text { wage } \\
\left(w^{P}\right)\end{array}$ \\
\hline Nonwhite & $\begin{array}{r}-.283 \\
(.134)\end{array}$ & $\begin{array}{l}.330 \\
(.184)\end{array}$ & $\begin{array}{l}.047 \\
(.043)\end{array}$ & $\begin{array}{l}-.077 \\
(.021)\end{array}$ \\
\hline Veteran & $\begin{array}{l}.501 \\
(.144)\end{array}$ & $\begin{array}{l}-.286 \\
(.156)\end{array}$ & $\begin{array}{l}-.009 \\
(.036)\end{array}$ & $\begin{array}{l}.023 \\
(.014)\end{array}$ \\
\hline Married & $\begin{array}{l}.179 \\
(.057)\end{array}$ & - & - & - \\
\hline Widowed, Div. or Sep. & $\begin{array}{l}.141 \\
(.128)\end{array}$ & - & - & - \\
\hline Central City & $\begin{array}{l}.320 \\
(.114)\end{array}$ & $\begin{array}{l}-.393 \\
(.195)\end{array}$ & - & - \\
\hline SMSA but not C. City & $\begin{array}{l}.526 \\
(.176)\end{array}$ & $\begin{array}{l}-.836 \\
(.227)\end{array}$ & & \\
\hline Nor theast & $\begin{array}{l}.036 \\
(.099)\end{array}$ & $\begin{array}{l}.271 \\
(.169)\end{array}$ & $\begin{array}{l}-.048 \\
(.034)\end{array}$ & $\begin{array}{l}.055 \\
(.017)\end{array}$ \\
\hline North Central & $\begin{array}{l}.375 \\
(.200)\end{array}$ & $\begin{array}{l}.187 \\
(.179)\end{array}$ & $\begin{array}{l}-.135 \\
(.044)\end{array}$ & $\begin{array}{l}.074 \\
(.014)\end{array}$ \\
\hline West & $\begin{array}{l}.307 \\
(.155)\end{array}$ & $\begin{array}{l}.143 \\
(.132)\end{array}$ & $\begin{array}{l}-.073 \\
(.046)\end{array}$ & $\begin{array}{l}.151 \\
(.017)\end{array}$ \\
\hline Percent Fed. Employment & - & $\begin{array}{l}26.023 \\
(5.782)\end{array}$ & - & - \\
\hline Unemployment Rate & $\begin{array}{r}-1.383 \\
(.535)\end{array}$ & - & $\begin{array}{l}.961 \\
(.277)\end{array}$ & $\begin{array}{l}.585 \\
(.221)\end{array}$ \\
\hline Years of Education & - & $\begin{array}{l}.061 \\
(.035)\end{array}$ & $\begin{array}{l}-.007 \\
(.015)\end{array}$ & $\begin{array}{l}.007 \\
(.008)\end{array}$ \\
\hline (Yrs. of Education) $2^{b}$ & - & $\begin{array}{l}-.017 \\
(.066)\end{array}$ & $\begin{array}{l}.175 \\
(.049)\end{array}$ & $\begin{array}{l}.151 \\
(.033)\end{array}$ \\
\hline Yrs. of Pot. Experience & - & - & $\begin{array}{l}.037 \\
(.004)\end{array}$ & $\begin{array}{l}.039 \\
(.001)\end{array}$ \\
\hline (Yrs. of Pot. Experience) ${ }^{2}$ & - & - & $\begin{array}{l}-.059 \\
(.007)\end{array}$ & $\begin{array}{l}-.063 \\
(.003)\end{array}$ \\
\hline
\end{tabular}


Table 2: Parameter Estimates for Males (cont'd)

\begin{tabular}{|c|c|c|c|c|}
\hline Variable & $\begin{array}{c}(1) \\
\text { Job Acceptance } \\
\text { Probability } \\
\left(P_{1}\right)\end{array}$ & $\begin{array}{c}(2) \\
\text { Job offer } \\
\text { Probability } \\
\left(\mathrm{P}_{2}\right)\end{array}$ & $\begin{array}{c}(3) \\
\text { Federal } \\
\text { Wage } \\
\left(w^{f}\right)\end{array}$ & $\begin{array}{c}(4) \\
\text { Private } \\
\text { Wage } \\
\left(w^{p}\right)\end{array}$ \\
\hline Professional & - & - & $\begin{array}{l}.440 \\
(.046)\end{array}$ & $\begin{array}{l}.448 \\
(.027)\end{array}$ \\
\hline Managerial & - & - & $\begin{array}{l}.381 \\
(.046)\end{array}$ & $\begin{array}{l}.496 \\
(.027)\end{array}$ \\
\hline Clerical & - & - & $\begin{array}{l}.329 \\
(.037)\end{array}$ & $\begin{array}{l}.243 \\
(.030)\end{array}$ \\
\hline Craft & - & - & $\begin{array}{l}.272 \\
(.041)\end{array}$ & $\begin{array}{l}.430 \\
(.025)\end{array}$ \\
\hline Operative & - & - & $\begin{array}{l}.103 \\
(.038)\end{array}$ & $\begin{array}{l}.304 \\
(.025)\end{array}$ \\
\hline Laborer & - & - & $\begin{array}{l}.059 \\
(.044)\end{array}$ & $\begin{array}{l}.186 \\
(.029)\end{array}$ \\
\hline $\operatorname{Ln} w^{f}$ & $\begin{array}{l}3.683 \\
(.229)\end{array}$ & $\begin{array}{r}-1.202 \\
(.345)\end{array}$ & - & - \\
\hline In $w^{2}$ & $\begin{array}{r}-2.275 \\
(.323)\end{array}$ & - & - & - \\
\hline Intercept & $\begin{array}{r}-4.873 \\
(.733)\end{array}$ & $\begin{array}{l}2.668 \\
(.823)\end{array}$ & $\begin{array}{l}1.291 \\
(.183)\end{array}$ & $\begin{array}{c}.897 \\
(.060)\end{array}$ \\
\hline
\end{tabular}

Covariance Matrix

Job Acceptance $\left(P_{1}\right)$

1.000

Job offer $\left(\mathrm{P}_{2}\right)$

$-.868$

$(.066)$

Federal wage $\left(w^{f}\right)$

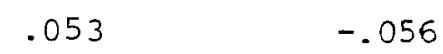

$(.042)$

(.037)

.121

$(.008)$

Private Wage $\left(w^{p}\right)$
.081
$-.266$
$(.048)$

.164 
Table 2: Parameter Estimates for Males (cont'd)

$\begin{array}{rr}\text { Log-Likelihood Funct } & \\ \text { Number of } & \text { observation } \\ \mathrm{N}_{00}: & 5626 \\ \mathrm{~N}_{01}: & 25 \\ \mathrm{~N}_{10}: & 32 \\ \mathrm{~N}_{11}: & 381\end{array}$

asymptotic standard errors in parentheses

${ }^{b}$ Scaled by 100 
Table 3: Parameter Estimates for Females ${ }^{a}$

\begin{tabular}{|c|c|c|c|c|}
\hline Variable & $\begin{array}{c}\text { (1) } \\
\text { Job Acceptance } \\
\text { Probability } \\
\left(P_{1}\right)\end{array}$ & $\begin{array}{c}(2) \\
\text { Job offer } \\
\text { Probability } \\
\left(\Xi_{2}\right)\end{array}$ & $\begin{array}{c}(3) \\
\text { Federal } \\
\text { Wage } \\
f f \\
\left(w^{f}\right) \\
\end{array}$ & $\begin{array}{c}\text { (4) } \\
\text { Private } \\
\text { wage } \\
p \text { p) } \\
(w)\end{array}$ \\
\hline Nonwhite & $\begin{array}{l}.177 \\
(.179)\end{array}$ & $\begin{array}{l}.100 \\
(.176)\end{array}$ & $\begin{array}{l}.021 \\
(.056)\end{array}$ & $\begin{array}{l}.018 \\
(.020)\end{array}$ \\
\hline Married & $\begin{array}{l}-.035 \\
(.064)\end{array}$ & - & - & - \\
\hline Widowed, Div. or Sep. & $\begin{array}{c}-.006 \\
(.071)\end{array}$ & - & - & - \\
\hline Central City & $\begin{array}{l}.644 \\
(.220)\end{array}$ & $\begin{array}{l}-.693 \\
(.295)\end{array}$ & - & - \\
\hline SMSA but not $C$ City & $\begin{array}{l}.995 \\
(.364)\end{array}$ & $\begin{array}{r}-1.073 \\
(.401)\end{array}$ & - & - \\
\hline Northeast & $\begin{array}{l}.930 \\
(.383)\end{array}$ & $\begin{array}{l}-.585 \\
(.353)\end{array}$ & $\begin{array}{c}-.129 \\
(.072)\end{array}$ & $\begin{array}{l}.069 \\
(.017)\end{array}$ \\
\hline North Central & $\begin{array}{l}.080 \\
(.141)\end{array}$ & $\begin{array}{c}-.022 \\
(.126)\end{array}$ & $\begin{array}{l}-.036 \\
(.047)\end{array}$ & $\begin{array}{l}.029 \\
(.016)\end{array}$ \\
\hline West & $\begin{array}{c}.297 \\
(.166)\end{array}$ & $\begin{array}{l}.075 \\
(.144)\end{array}$ & $\begin{array}{c}-.071 \\
(.050)\end{array}$ & $\begin{array}{l}.119 \\
(.016)\end{array}$ \\
\hline Percent of Fed. $L$ yment & - & $\begin{array}{l}16.098 \\
(4.500)\end{array}$ & - & - \\
\hline Unemployment Rate & $\begin{array}{c}-4.427 \\
(1.823)\end{array}$ & - & $\begin{array}{l}1.238 \\
(.566)\end{array}$ & $\begin{array}{l}.105 \\
(.253)\end{array}$ \\
\hline Yrs. of Education & - & $\begin{array}{l}.425 \\
(.103)\end{array}$ & $\begin{array}{c}-.077 \\
(.024)\end{array}$ & $\begin{array}{l}.002 \\
(.011)\end{array}$ \\
\hline (Yrs. of Education) $2^{b}$ & - & $\begin{array}{r}-1.427 \\
(.386)\end{array}$ & $\begin{array}{l}.383 \\
(.092)\end{array}$ & $\begin{array}{l}.128 \\
(.046)\end{array}$ \\
\hline Yrs. of Pot. Experience & - & - & $\begin{array}{l}.026 \\
(.005)\end{array}$ & $\begin{array}{l}.019 \\
(.001)\end{array}$ \\
\hline (Yrs. of Pot. Experience) $2^{b}$ & - & - & $\begin{array}{l}-.043 \\
(.010)\end{array}$ & $\begin{array}{l}-.034 \\
(.003)\end{array}$ \\
\hline
\end{tabular}


Table 3: Parameter Estimates for Females (cont'd)

\begin{tabular}{|c|c|c|c|c|}
\hline Variable & $\begin{array}{c}(1) \\
\text { Job Acceptance } \\
\text { Probability } \\
\left(P_{1}\right)\end{array}$ & $\begin{array}{c}(2) \\
\text { Job offer } \\
\text { Probability } \\
\left(\mathrm{P}_{2}\right)\end{array}$ & $\begin{array}{c}\text { (3) } \\
\text { Federal } \\
\text { Wage } \\
f\left(w^{f}\right)\end{array}$ & $\begin{array}{l}(4) \\
\text { Private } \\
\text { Wage } \\
\left(w^{p}\right)\end{array}$ \\
\hline Professional & - & - & $\begin{array}{l}.555 \\
(.091)\end{array}$ & $\begin{array}{l}.516 \\
(.022)\end{array}$ \\
\hline Managerial & - & - & $\begin{array}{l}.422 \\
(.077)\end{array}$ & $\begin{array}{l}.465 \\
(.023)\end{array}$ \\
\hline Clerical & - & - & $\begin{array}{l}.380 \\
(.063)\end{array}$ & $\begin{array}{l}.302 \\
(.016)\end{array}$ \\
\hline Craft & - & - & $\begin{array}{l}.281 \\
(.102)\end{array}$ & $\begin{array}{l}.389 \\
(.036)\end{array}$ \\
\hline Operative or Laborer & - & - & $\begin{array}{l}.138 \\
(.072)\end{array}$ & $\begin{array}{l}.245 \\
(.021)\end{array}$ \\
\hline Ln $w^{f}$ & $\begin{array}{l}2.902 \\
(.178)\end{array}$ & $\begin{array}{l}-.757 \\
(.324)\end{array}$ & - & - \\
\hline In $w^{p}$ & $\begin{array}{r}-1.697 \\
(.430)\end{array}$ & - & - & - \\
\hline Intercept & $\begin{array}{r}-3.795 \\
(.992)\end{array}$ & $\begin{array}{l}-.736 \\
(.390)\end{array}$ & $\begin{array}{l}1.647 \\
(.246)\end{array}$ & $\begin{array}{c}.955 \\
(.080)\end{array}$ \\
\hline
\end{tabular}

Covariance Matrix

$\begin{array}{ll}\text { Job Acceptance }\left(P_{1}\right) & 1.000\end{array}$

Job offer $\left(\mathrm{P}_{2}\right) \quad \begin{array}{ll}-.920 & 1.000 \\ & (.051)\end{array}$

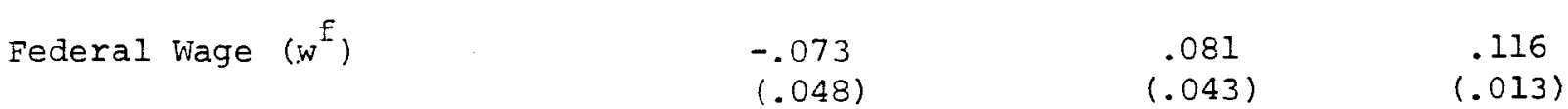

$\begin{array}{llcc}\text { Private Wage }\left(w^{p}\right) & .004 & -.146 & -135 \\ & (.058) & (.066) & (.055)\end{array}$ 
Table 3: Parameter Estimates for Females (cont'd)

Log-Likelihood Function: $\quad-2727.74$

Number of Observations: $\quad 4561$

$\begin{array}{lr}\mathrm{N}_{00}: & 4339 \\ \mathrm{~N}_{01}: & 14 \\ \mathrm{~N}_{10}: & 16 \\ \mathrm{~N}_{11}: & 192\end{array}$

a) Asymptotic standard errors in parentheses

b) Scaled by 100 
Table 4: Predicted Percentage Federal-Private Wage Differences ${ }^{a}$

\begin{tabular}{lcc}
\hline Method of Estimation & Males & Females \\
\hline Sample Mean & & 38.7 \\
& 32.8 & \\
OLS $^{\mathrm{C}}$ & & 22.6 \\
& 11.7 & $(2.6)$ \\
$\mathrm{OLS}^{\mathrm{d}}$ & $(2.1)$ & 20.3 \\
& 12.1 & $(2.5)$ \\
$\mathrm{MLE}^{\mathrm{e}}$ & $(2.0)$ & 22.1 \\
& 4.2 & $(7.9)$ \\
\hline
\end{tabular}

a standard errors in parentheses.

$\mathrm{b}_{\text {Unadjusted }}$

${ }^{C}$ Adjusted for observed productivity characteristics listed in column 3 of Tables 2 and 3 .

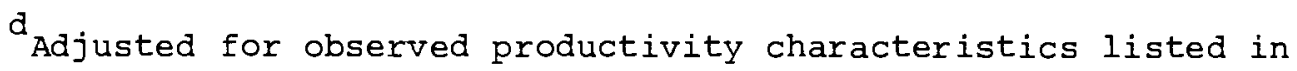
column 3 of Tables 2 and 3 and indicators of part-time work, widowed, divorced, or separated, married, two urbanization dummies, and five additional product terms between the included variables.

edjusted for observed productivity characteristics listed in column 3 of Tables 2 and 3 and unobserved productivity differences. 
Table 5: Simulated Probabilities

\begin{tabular}{lll}
\hline & Males & Females \\
\hline (1) $\begin{array}{l}\text { Probability of } \\
\text { Job Acceptance }\left(P_{1}\right)\end{array}$ & 0.180 & 0.286 \\
(2) Probability of \\
$\begin{array}{l}\left.\text { Job Offer ( }{ }_{2}\right) \\
\text { (3) Joint Probability of }\end{array}$ & 0.829 & 0.676 \\
Employment Match & 0.064 & 0.047 \\
(4) Length of Queue & 2.811 & 6.107 \\
\hline
\end{tabular}

Source: (1): $\frac{1}{n} \sum_{i=1}^{n} \operatorname{Pr}\left(P_{1}>0\right)$

(2): $\frac{1}{n} \sum_{i=1}^{n} \operatorname{Pr}\left(P_{2}>0\right)$

(3): $\frac{1}{n} \sum_{i=1}^{n} \operatorname{Pr}\left(P_{1}>0, P_{2}>0\right)$

(4): (1)/(3) 